\title{
Influence of Speech Anxiety on Oral Communication Skills among ESL/EFL Learners
}

\author{
Said Muhammad Khan \\ Department of Applied Linguistics, Yanbu University College, PO box 31387, Yanbu Industrial City 41912, Saudi Arabia \\ E-mail: said.english@gmail.com
}

Doi:10.7575/aiac.alls.v.6n.6p.49

URL: http://dx.doi.org/10.7575/aiac.alls.v.6n.6p.49
Received: $15 / 06 / 2015$

Accepted: 28/08/2015

\begin{abstract}
The realization of speech anxiety among ESL/EFL learners is important. Once understood, these feelings of fear or nervousness may be relieved and the desired objectives of learning the target language may be achieved. The study has attempted to measure the level of anxiety among ESL/EFL learners at HITEC University, Taxila, Pakistan. The current research has arrived at the conclusion that the target population is highly anxious in situation where they are required to speak English. The findings show that sources such as pedagogical, psychological, socio-economic, linguistic and cultural generate anxiety among the EFL learners. The study has suggested variety of strategies to treat anxiety in the academic context. It was found that communicative approach in classroom may be helpful in minimizing the negative impact of anxiety among language learners.
\end{abstract}

Keywords: speech anxiety, communicative approach, communication apprehension, FLA

\section{Introduction}

With the globalization, the university graduates are expected to be confident in oral communication so that they can function effectively in the academic and professional settings. Allen (2002) arrived at the conclusion that having confidence in oral communication can make graduates versatile in their personal, academic, professional and civic lives. To fulfill the demands of highly communicative global village, English has become the most desired language of the world. Every year, a lot of books are published and billions of dollars are utilized for learning English as a second or foreign language. Whenever such learners endeavor to learn and speak English either as a second or a foreign language, they experience a certain level of anxiety and claim to undergo a 'mental block' during oral communication (Horwitz et al., 1986). Researchers have found that this mental block or anxiety severely jeopardizes the language learners' communicative competence. Despite the international market demands for a confident workforce with clear oral communication in English, researchers like Devi et al. (2008) found that most of the language learners have some form of anxiety that interferes with their level of confidence during their speech. This aspect of language and communication is called speech anxiety. Anxiety shakes the language learners' confidence which adversely impedes their oral performance in the target language. Being fully aware of the debilitating effects of the multi-faceted dilemma of language anxiety, the present research project is deemed important in order to gain fuller understanding of communication apprehension and devise effective strategies to overcome anxiety in ESL/EFL classrooms.

\subsection{Statement of the Problem}

Anxiety or low level of confidence restricts the chances of learning and speaking the target language hence pose serious threat to oral communication. Richmond and McCroskey (1989) opined that the high level of anxiety among language learners seriously hampers the interaction between teacher and learners which is extremely crucial to productive teaching and learning of the target language. Since anxiety is a multi-faceted dilemma language barrier for ESL/EFL learners, therefore this problem needs to be studied, discovered its sources and cured in the Pakistani academic setting.

\subsection{Data Collection}

Data for the current research was collected from students of HITEC University enrolled in Communication Skills course. At a first step, Foreign Language Classroom Anxiety Scale - FLCAS questionnaire (adopted from Horwitz et al. 1986) was distributed to gauge the level of anxiety among the students of BS Mechanical Engineering $3^{\text {rd }}$ semester. Approximately Two hundred students were enrolled in communication skills class in Fall 2011 semester. At the second step ten participants (five students, having highest score and five students having lowest score according to the FLCAS scale) were selected for a structured interview. The interview provided opportunity to the researcher to analyze the factors and influence of anxiety both among high anxious and low anxious students.

\subsection{Research Questions}

1. What is the level of speech anxiety among EFL/ESL Learners at HITEC University?

2. What are the main causes of speech anxiety among these learners?

3. How far the speech anxiety affects students' learning oral communication skills? 
One of the major objectives of the research study is to measure the level of apprehension among English language learners especially in the Pakistani context. Measuring the level of anxiety may be helpful in developing teachers and students' awareness regarding anxiety and its negative influence on oral communication. Discovering the sources that provoke anxiety among language learners has also been one among many objectives of the study. Diagnosing the anxiety-provoking factors may be helpful in devising effective medication for this unsettled phenomenon. To know the negative influence of anxiety on oral communication has also been one among the objectives of the research study. Realizing the importance of oral communication in the contemporary world, the study may be supportive for language instructors, students and policy makers to make EFL/ESL learners confident communicators if incorporated in language pedagogy.

\section{Literature Review}

Speech anxiety is broadly used to refer to the apprehension experienced by an individual when required to speak either in L1 or L2. Horwitz et al (1986) define this anxiety 'as a type of shyness characterized by fear or apprehension about communicating [orally] with people.' MaCroskey, (1970) defines it simply as a fear related to oral communication. physical, psychological, social and temporal dimensions of context play a critical role in speech. Listeners' status and the context make the speaker uneasy and apprehensive to speak confidently. Friedman, 1980 (as cited in Taylor, 1987) claims that speech anxiety may be specific to just a few setting e (e.g. public speaking) or may exist in most everyday [oral] communication situations or may even be part of general anxiety trait that arises in many facets of an individual' life. Among all four language skills, speaking is supposed to be the most anxiety-provoking skill. MacInttyre and Gardner (1991) have pointed out that the skill producing most anxiety is oral communication. We can simply conclude on what Scovel (1991) believes that anxiety a state of nervousness and hesitation or fear caused by the expectation of something intimidating.

Speech anxiety is a general phenomenon experienced by majority of L2 learners effecting both language and educational achievements. Horwitz (2001) believes that anxiety is perceived intuitively by many language learners, negatively influences language learning and has been found to be one of the most highly examined variables in all of psychology and education.

Speech anxiety/apprehension is a part of broader concept of language anxiety. Horwitz and Cope (1986) suggest that language anxiety has three components: 1) communication apprehension 2) test anxiety 3) fear of negative evaluation. Learners who demonstrate speech anxiety/communication apprehension feel uncomfortable when required to communicate orally in the target language in front of others. Students who experience test anxiety consider oral production as a test situation rather than a chance for improving communication skills (Tesiplakides, 2009). Learners who exhibit fear of negative evaluations deem errors as a danger to their image not as an accepted part of learning process. As a consequence, they are silent and do not participate in activities in ESL classroom (Ely 1986)

\subsection{Influence of Anxiety on Speaking Skills}

Speech anxiety makes language learners frightened and shakes their confidence which results in avoidance and withdrawal from speaking activities in EFL/ESL classes. McCroskey (1984) found that if students with high speech anxiety are given the opportunity to choose their subjects, they would probably prefer those subjects where speaking skills are not focused. High apprehensive language learners cannot organize his/her speech properly and deliver confidently which makes them reticent and shy. They think about the anticipated threat rather than selection of words and organization of ideas. Malimabe, (1997) believes that whenever a student with high levels of Speech anxiety tries to engage himself/herself in oral communication he/she becomes irrelevant at times and prefer to be in a large, rather than in a small group asking no question in the class. Since L2 learners' thinking process is infected by fear and uneasiness when they speak, it also effect both content and manner of the message they want to convey in the target langue. (Zheng, 2008) claims that anxiety influence both speed and accuracy and its arousal can impact even the quality of communication output as the retrieval of information may interrupted by the 'freezing-up' moments that students encounter when they get anxious Richmond and Falcoine (1977) discovered that learners with high levels of Speech anxiety were predisposed to have poorer self-esteems than students with low Speech anxiety which in turn affects academic success negatively. Students, who participate in classroom discussion, usually get more attention and welcoming treatment from the instructors but shy students are considered back-benchers and dull. McCroskey and Daly (1976) concluded that even instructors tend to ignore or consider learners with high Speech anxiety or apprehension as low achievers, and as a result, do not expect much from them.

\section{Research Methodology}

A blend of both quantitative and qualitative methods (pragmatic approach) was adopted for the intended research. Data collected through FLCAS questionnaire was analyzed quantitatively and data collected through interviews was investigated qualitatively. Due to this very fact, the result of the research reflects both the approaches. Data collected via FLCAS from 200 students enrolled in communication skills course was examined quantitatively to measure the level of speech anxiety among EFL learners. Based on the result of the questionnaire 10 subjects (Five high anxious and five low anxious) were selected for semi structured interviews. Data collected via interviews from high as well low anxious subjects was analyzed qualitatively. The detailed interviews with the 10 selected participants helped the researcher to correlate and authenticate the findings of FLCAS questionnaire and also validate the findings of previous researchers. 


\section{Findings and Discussion}

Based on the result of FLCAS questionnaire, 10 students were selected for interviews. Five high anxious students were interviewed along with five less anxious students. Questions related to anxiety-provoking factors, symptoms of anxiety and remedies of anxiety were asked from all the 10 selected subjects. The following factors were held responsible for anxiety by the subjects.

\subsection{Pedagogical Factors}

The ten selected subjects of the study continuously referred to pedagogical factors and held them responsible for their high as well as low level of speech anxiety during their interviews. Pedagogical sources were declared the most important factors that produce anxiety among ESL/EFL learners in a language classroom. These instructional sources are the combination of stressful classroom environment and language teachers' teaching methodology.

Evaluative and stressful classroom settings were referred to, as the main source of high and low levels speech anxiety by the selected subjects of the current study. During the interview session, the high anxious subjects pointed out that classroom is a place where they are judged, their mistakes are highlighted, and their grades are affected whenever they take part in any speaking activity. This type of feelings can be very easily observed in the remarks of one of the highapprehensive subjects when he says, “...when I speak ... I think people are jugging me". The other high anxious subject blamed his fellow students and the teacher by saying "our English teacher and the students make strange facial expressions and look on me when I speak English in the class. There strange look and smile make afraid". This shows that classroom environment is not supportive and learners are not encouraged to speak. All these remarks given by high and low anxious participants of this research indicate that EFL/ESL classroom environment can be a major source of apprehension for learners of a language which is consistent with the findings of Tusi (1996) and Daly (1991).

4.1.1 Poor Educational and Economic Background

In accord with the findings of previous researchers such as Khattak Z. et al. (2011), I also found that the ESL/EFL learners' poor educational as well as poor economic background is one among the major sources of speech anxiety. The less anxious participants of this study gave due credit to their schooling and previous educational background for their confidence and communicative competence. In response to the researcher's question regarding the reasons of his low anxiety, one of the two confident subjects replied, “... [The] reason of my low level of anxiety while speaking English $\ldots$ the first and foremost is my schooling. We were provided with an environment where teachers and students mostly communicated in English Language. Secondly, daily assemblies were conducted in which students had to present and perform in English Language which boosted my confidence a great deal and helped me overcoming the fear of audience"

4.1.2 Psychological Factors

During the interviews with the selected participants, psychological sources were also held responsible for language learners' high as well as low levels of apprehension. There are various psychological variables that make ESL/EFL learners anxious in setting where they are required to speak English. These diverse psychological variables e.g. learners' personality traits, and learners' self-perception that have been highlighted by the subjects

Analyzing the interviews of 10 selected participants, the current research found that personality traits, such as extraversion as well as introversion are directly linked to low or high level of anxiety. The introvert language learners are more vulnerable and expected to be anxious in circumstances where they have to communicate in English. During the interview with the researcher, one of the high anxious subjects replied, "I am not friendly, I do not like talking to people, and mixing up with them. I am not very talkative"

Some previous researchers on language anxiety have reached the conclusion that learners' apprehension may be aggravated by their perfectionist tendencies (Gregresen and Horwitz, 2002) and learners self-related perception (Krashen, 1985). After analyzing the interviews, the current research has also diagnosed a few self-related perceptions among the subjects of this study which is consistent with the findings of previous researchers on language anxiety. Tobias (1986) found that highly apprehensive learners think negative about their own selves and have low-perceived self-esteem about their own performance in the target language. The same negative thoughts about their selves are very clear in the remarks of highly anxious subjects during the interview. One of the participants said, "And during speaking I feel that if I speak wrong, all the people will laugh on [at] me and then I can't speak English correctly"

4.1.3 Linguistic Factors

The previous researchers on language anxiety such as Lightbown and Spada (2006) and Tanveer (2007) have reported that English language pronunciation, irregular grammar rules and vocabulary are also responsible for speech anxiety in situation where learners are required to communicate in English Language The current research has also found that linguistic factors aggravate student's anxiety which needs to be investigated and researched.

After in-depth analysis of the interviews with the subjects, the current research reached at the conclusion that Pakistani ESL/EFL learners commonly think in their native language and then translate it into English during their oral communication. This translation from native language to English impedes learners' fluency which causes anxiety in formal settings. One of the highly anxious subjects replied to a question during an interview, "before speaking I make sentences in my own language, and I convert it, but when I go to speak it, I can't speak it with exact vocabulary...” 


\subsubsection{Social Factors}

The previous researchers on FLA believe that socio-cultural factors cause more fear among EFL learners than the other factors. The present research has also discussed three different aspects of social factors (limited exposure to L2, learners' family background, and social status) responsible for provoking anxiety among ESL learners in Pakistan.

During the interview session, the subjects of this study gave mild discredit to their limited exposure in the target language for their anxiety. This limited exposure badly affects learners' fluency in the target language which results in apprehension in situation where they are required to speak the target language (Lightbown and Spada, 2006). When I asked one of the highly anxious subjects of this study regarding the reasons of his anxiety, he replied, "The main reason is that we haven't [been] provided [with] any environment for speaking English". Feelings of the same type are also reflected in the expressions of another high anxious subject when he says, "Since speaking in English is something new for me, so I make many mistakes and these mistakes make me worried".

The intended research has concluded from the interviews of highly anxious learners that they consider English language as a status symbol. The one who speaks English in accent like native speakers is considered wealthy and talented as one of the participants said, "Yes it gives extraordinary status when you speak English like American or British. People consider you talented. If you are a good speaker, you impress them" These remarks of the high apprehensive subjects of the study clearly indicate that they use English as a status symbol rather than just a tool to communicate. These feelings of associating social class with language make them think inferior, that trouble fluency and trigger anxiety when they speak in the target language. This association of language with a status symbol or with some ones talent makes the EFL/ESL learners suffer from inferiority complex. These feelings of inferiority trouble learners' fluency that results in nervousness and communication apprehension as Pica (1987) found that difference between speaker's and listener's status may also be one factor of speech anxiety.

\subsection{Impact of Speech Anxiety}

Speech anxiety makes language learners frightened and shakes their confidence which results in avoidance and withdrawal from speaking activities in EFL/ESL classes. One of the high apprehensive subjects of this study revealed in response to the question of influence on anxiety on his language, "Due to fear I cannot speak well, otherwise when I am alone, I really make good dialogues. I think in English alone. I think the main reason of my poor English is my confidence, my confidence level is very low. I can't speak in front of others even if I know the answer". These remarks of an anxious subject clearly show a very alarming situation that anxiety negatively influences learners' speech and doesn't let them speak even if they have enough information. In connection with the same question another high anxious participant said, "I am teaching tuition to my brother, I speak better English, I feel very confident at that time. But in front of teacher and the classmate I forgot every thing". Both the statements of subjects who experience high anxiety clearly show that anxiety cast negative influence on learners' productive skills and EFL instructors need to consider this multi-faced phenomenon.

\subsection{Remedies of Speech Anxiety}

The participants of this study, in their interviews, suggested change in their classroom environment. They think that strict classroom settings must be replaced with friendly environment where one can speak and practice the target language easily. In the strict formal place, students fear making mistakes and this fear does not let them practice the new language. One of the high anxious subjects suggested, "I will request all teachers to be friendly in the class, please not make strange expressions at their students. They should ignore our mistakes. They should focus on speaking"

To make the language learners comfortable and classroom less anxiety-producing place, the language instructor's role has been declared important. A language teacher plays an important role in both decreasing as well as increasing anxiety of language learners. The participants of this study suggested that a language teacher must be friendly, focusing communicative competence of learners and tolerating learners' mistakes. One of the participants, suggested, "I would request the teacher also, not just to teach grammar rules, but use English for communication, encourage students to speak...tolerate students mistakes, be friendly. And must not deduct marks on speaking mistakes".

Classroom environment is stated extremely crucial when it comes to language anxiety and apprehension. The participants of this study showed that classroom procedure and continuous evaluation of their activities make them apprehensive as this affects their grades in their entire academic careers. Eliminating and minimizing the other anxiety provoking factors will also play pivotal role in decreasing foreign language anxiety.

\section{Conclusion}

Hence it goes without saying that speech anxiety and apprehension is the major problem of English language learners that impedes their communicative competence. In Pakistan, English is taught to students since Kindergarten, but students lack confidence and effective communication skills. Despite studying English for years, having sufficient linguistic competence, students at the University level lack effective speaking skills. Since they have all the required linguistic knowledge but due to their lack of confidence they can speak the target language confidently. In this highly communicative world, students' communication skills are as necessary as other professional skills. This lack of confidence is a serious threat to English language learners' communicative behavior which leads to avoidance behavior. As practice makes a man perfect and language has to be practiced if one wants to learn and speak well. Once a learner stops practicing the target language, speaking skills can never be developed and whenever the learner is supposed to speak English, he/she will be confused, nervous and anxious. 
Gaining effective oral communication skills in English is a multidimensional process which depends on various factors. Low confidence of ESL/EFL learners during their speech is the total sum of the outcome of all the factors discussed above. Among these anxiety-proving factors, socio-economic and cultural factors of the language learners have been investigated in the study. However these are the not the only factors responsible for learners' anxiety, teachers' communicative competence, instructors' training, their beliefs and attitude coupled with methodology have also been proved responsible for language learners' anxiety.

\section{References}

Allen, T. (2002). Charting a communicative pathway: Using assessment to guide curriculum development in a revitalized general education plan. Communicative Education, 51(1), 26 - 39.

Daly, J. (1991). Understanding communication apprehension: An Introduction for language educators. In E. K. Horwitz \& D. J. Young (Ed.), Language anxiety from theory and research to classroom implications. New Jersey: Prentice Hall. Devi, S. I. \& Feroz F. S. (2002). Oral communication apprehension and communicative competence among Electrical Engineering undergraduates in UTeM. Journal of Human Capital Development, 1(1), 1-10.

Ely, C. M. (1986). An analysis of discomfort, risk taking, sociability and motivation in the L2 Classroom. Language Learning, 36, 1-25.

Gregersen, T., \& Horwitz, E. K. (2002). Language learning and perfectionism: Anxious and non-anxious language learners' reactions to their own oral performance. The Modern Language Journal, 86(4), 562-570.

Horwitz, E. K., Horwitz, M. B., \& Cope, J. (1986). Foreign language classroom anxiety. The Modern Language Journal, 70, 125-132.

Horwitz, M. B., Horwitz, E. K., \& Cope, J. (1991). Foreign language classroom anxiety. In E. K. Horwitz \& D. J. Young (Ed.), Language anxiety: From theory and research to classroom implications, Englewood Cliffs, NJ: Prentice Hall.

Horwitz, E. K., Horwitz, M. B., \& Cope, J. (1986). Foreign language classroom anxiety. The Modern Language Journal, 70, 125-132.

Horwitz, E. K. (2001). Language anxiety and achievement, Annual Review of Applied Linguistics, 21, 112-126.

Khattak, Z. I., Jamshed, T., Ahmad, A., Baig, N. M. (2011). An investigation into the causes of English language learning anxiety in students at AWKUM. Procedia Social and Behavioral Sciences, 15(20), 1600-1604.

Krashen, S. D. (1976). Formal and informal environment in language acquisition and language learning. TESOL Quarterly, 10, 157-168.

Krashen, S.D. (1985). The Input Hypothesis: Issues and Implications. New York: Longman

Lightbown, P. M., \& Spada, N. (2006). How languages are learned. $3^{\text {rd }}$ edi., United Kingdom: Oxford University Press. MacIntyre, P. D., \& Gardner, R. C. (1991). Language anxiety: Its relationship to other anxieties and to processing in native and second languages. Language Learning, 41, 513-534.

Malimabe, M.M. (1997). Communication apprehension in Qwaqwa secondary schools. MA dissertation. Potchefstroom University for Christian Higher Education.

Mccroskey, J. C. \& Daly, J.A. (1976). The teacher's expectations of the communication apprehensive child in the elementary school. Retrieved from http://www.jamescmccroskey.com

Mccroskey, J. C. (1984). The communication apprehension perspective. Retrieved from http://www.jamescmccroskey.com

Onwuegbuzie, A, J., Bailey, P., \& Daley, C. E. (1999). Factors associated with foreign language anxiety. Applied Psycholinguistics, 20(2), 217-239.

Pica, T. (1987). Second language acquisition, social interaction and the classroom. Applied Linguistics, 8 (1), 3-21.

Richmond, V.P. \& Falcione, R.L. (1977). Studies of the relationship between communication apprehension and selfesteem. Human Communication Research. Retrieved from http://www.jamescmccroskey.com

Richmond, V. P., \& McCroskey, J. C. (1989). Communication: apprehension, avoidance, and effectiveness, 5th ed. Needham Heights, MA: Allyn and Bacon.

Scovel, T. (1991). The Effect of affect on foreign language learning: A review of the anxiety research. Language Learning, 28(10), 129-41.

Tanveer, M. (2007). Investigation of the factors that cause language anxiety for ESL learners in learning speaking skills and influence it casts on communication in the target language, M.Ed. ELT thesis. University of Glasgow.

Taylor, H. H. (1987). Communication apprehension: The quiet student in your classroom, ERIC Clearinghouse on Reading and Communication Skills Urbana IL.

Tobias, S. (1986). Anxiety and cognitive processing of instruction. In R. Schwarzer (Ed.), Self-related cognition in anxiety and motivation. Hillsdale, $\mathrm{NJ}$ : Erlbaum.

Tsui, A. B. M. (1996). Reticence and anxiety in second language learning. In K. M. Bailey \& D. Nunan (Eds.), Voice from the language classroom (pp. 145-167). New York: Cambridge University Press.

Young, D. J. (1992). Language anxiety from the foreign language specialist's perspective: interviews with Krashen, Omaggio Hadley, Terrell, and Rardin. Foreign Language Annals, 25, 157-172.

Zheng, Y. (2008). Anxiety and second language learning revisietd. Canadian Journal for New Scholars in Education , 1 (1), 1-12. 